\title{
TURKEY AS A REGIONAL LOGISTIC HUB IN PROMOTION OF REVIVALING ANCIENT SILK ROUTE BETWEEN EUROPE AND ASIA
}

\author{
DOI: 10.17261/Pressacademia.2015211609
}

\author{
A. Zafer Acar ${ }^{1}$, Zbigniew Bentyn², Batuhan Kocaoglu ${ }^{3}$ \\ 1Piri Reis University. a.zaferacar@gmail.com \\ ${ }^{2}$ Poznan University of Economics. zbigniew.bentyn@ue.poznan.pl \\ ${ }^{3}$ Okan University. batuhan.kocaoglu@okan.edu.tr
}

\section{Keywords}

International logistics, transport, logistic performance, trade, infrastructure.

\section{JEL Classification} F1, F4, L91, R4

\begin{abstract}
Since the ancient times the path between two continents led always through Turkey. Valuable merchandise traveled the famous Silk Road and allows creating a profitable trade for both sides of the known world. From international logistic perspective this process although risky and costly was a condition for future development of both regions. Today is also visible that maintaining an efficient and save route between both mentioned economically potent parts of the world is a crucial condition for trade increase and future development. This fresh outlook can be also complemented by the increase of global competitiveness unrepresented in ancient times. The purpose of this paper is to present Turkey as a developing hub for future connection between Europe and Asia. A vast investments already made in projects ensuring revival of ancient route indicate a modern approach to the task of connecting economical potential from both sides of Eurasia. The logistic performance index shows perceived progress in Turkey, critical region for the route. The present and future projects can increase the tempo of logistical development even faster. There is a viable business for both European and Asian regions to create a useful logistical hub between them. And the location of it becomes clear as data suggest.
\end{abstract}

\section{INTRODUCTION}

An increase in competitiveness between word regions is an undeniable factor thanks to globalization processes. Focusing attention of international investors can be both expensive and profitable occupation. The tools of global logistics: fast and intraoperative modes of transportation, reliable logistical centers and information systems virtualizing global supply net. The goal is to interconnect geographically spanned parts of the world in the process of creating a market value. Although risk involved in the process forces the managers to many activities increasing reliability of the logistics operation. That is also the reason why the direct investment is related with perceived logistic performance and influences the development of the region. The demanding market created by the competitive companies for the impatient customers increase a value of the time of delivery and cost of the logistic and production operations. The source for security and increased reliability lies in the infrastructure. Logistical infrastructure allowing of transport and warehousing operations to be connected to the net of data exchange, gives control exercised from global perspective. That is why the development of economy and trade starts with building the roads and ports. Nowadays infrastructure means control and flexibility in the supply chain. 
Constant changes in demand and increased role of mass customization forces entrepreneurs to quick response concerning resources involved in the processes of creating value. To have ability to adjust in the process of changing demand means to decrease the logistical cost an open the route for even greater integration up in the supply chain. The regions which understood this fact years ago present today a mighty force in logistic performance. From the all regions of the world it happens to be Europe where lies seven of the ten best countries in global logistical performance ranking presented by The World Bank in 2014 (Ipi.worldbank.org, 2014). The region called "blue banana" connecting the heaviest populate part of the Europe, between port in Rotterdam North and Median South, as a logistical hub of Europe present an exquisite performance in available infrastructure for logistic operations. Eurologistics as a way of doing business in Europe is a model of development cross border cooperation sustaining and improving existing net of transportation. Over 50 years of common effort between members of UE helped to create a very efficient a region from logistical point of view. The assessment of logistical performance is an important factor in the process of building competitive region. The data gathered by independent institution showing trends concerning countries and global regions. Analysis of this data gives an outlook for conclusions about the future development chances and threats. In this context this paper organized as fallows. After this part the LPI index will be expressed as a measurement tool. Then, third chapter is dedicated to European trade development and tendencies. Chapter four presents Asian development as production hub of the world. Finally routes for trade between Asia and Europe throughout Turkey will be indicated.

\section{LPI INDEX SUBJECTIVE BUT COMPARABLE MEASURMENT}

In attempt to develop a strong export potential in any country or a region it is a basic step to prepare logistical conditions up to the level where such activities actually support trade. It is especially critical for a country of origin to increase service delivery performance. As Behar, Manners and Nelson stated improving services in international logistic activities help to increase an export especially for the countries which represent an economic and geographical potential - bigger than average. Their study shows that for any country despite differences in scale and economy potential, logistics improvement is equivalent to a $14 \%$ reduction in distance (Behar et al., 2013). An obvious strength in logistics performance allows bringing countries closer and increase trade. From that point of view an interesting ranking is prepared by The World Bank reports from 2007, than 2010 and then every two year later, 2012, 2014. Comparison of Logistics Performance Index of over 100 countries from the word (160 countries in recent edition) gives a quick view on preparation level for joining an international exchange. The LPI index is rather complex assessment. It is combined from six various dimensions. The first one consists of the efficiency of customs and border clearance. As an administrative obstacle to overcome it may be a barrier for trade decreasing the speed and availability of product on designated market. The first part is named shortly as Customs. Second part is dedicated for evaluation an infrastructure which is may be a backbone of an industry when in good shape. The quality of transport infrastructure influences trade and decreases investment in warehousing since the majority of the product may be easily delivered by efficient transport systems. 
For the report this part is called Infrastructure. Next part allow to judge ease of arranging shipments, especially in international trade. Logistics operators are valuable partners in maintaining the flow during constant global logistics operations. Without a competitive force on the market of logistics services it is difficult to keep the cost of delivery at bay. Evenly important is the competence and quality of logistics services. In this section it is judged if: trucking, forwarding, and customs brokerage are conducted in professional manner. For the summary it is called the quality of logistics services. The supply chain management requires more control every year. This tendency gives the managers abilities to prepare operations in supply chain for a sudden change. The market as a source of irregularities and demands a constant adjustment. That leads to desired increased level of control. Part of this tendency is visible in providing tracking and tracing services. This is also an additional opportunity to decrease the cost of transport thanks to available software observing the congestion in dense areas and helping to choose an optimal route for the cargo. The last but often the most important factor is the Timeliness. Scheduled delivery should reach its destination without the delay. The frequency of such events increases an overall timeliness. The tendency to decrease the timeliness is threatening and in some cases may be a serious barrier for foreign trade (Arvis et al., 2014).

In the year 2014 the 160 countries in the world was judged in above mentioned categories thanks to 6000 assessments. Those were prepared by logistic professionals with knowledge about procedures in and conditions in given country. The general idea behind the LPI index lays in increase the connectivity between word regions. This connectivity is understood as an importance of the country, airport, and seaport for the international net of logistics. The central position of a certain place allows international business to expand its reach and use an above average potential in maintaining supply chain operations. Becoming a central in this light means reducing economic distance, increase efficiency in supply chain, and connectivity with the other regions (Arvis \& Shepherd, 2011). An infrastructural transportation projects have this power to overcome a given geographical conditions. That helps different locations to decrease a distance and therefore cost of connection between them. Thus may naturally lead to flourishing the trade and improve partnership in-between companies creating international supply chain.

Thanks to a continued effort to asses logistics activities in the regions and the LPI index unchanged methodology The Word Bank provide a useful tool to compare countries progress over time. The evolution in logistics mat be used a symptom of development and increased speed of building international supply chains. The services provided in the observed area are proving existing viable business activities (Shepherd, 2013). This may be transformed in to an overall economy perspective. The recent data is drawing an image of change in the world of logistics and business. The emerging regions are Eastern Europe and Central and South Asia. Those regions develop its strength based on production and distributions. An emerging need to connect and logistic services between those regions is increasing. Additionally to this conclusion is an observed fact that logistic performance is connected with income per capita. The developed countries invest more and perform better in comparison to developing countries. Observing a country in the scope of LPI index gives a valuable perspective. Time related changes show tendencies and help to recognize direction of changes. 
Other developments and changing which support Turkey's position as a regional logistics hub may be used in developing a strategy to connect regions and help to maintain a positive tendency in developing logistical performance.

\section{DEVELOPMENTS AND CHANGES WHICH SUPPORT TURKEY'S POSITION AS A REGIONAL LOGISTIC HUB}

The choice of connection between remote regions of the world depends on many factors including the development of new technologies. The inventions in transportation technology help to draw different routes to connect far locations. The recent development of maritime transportation and containerization changed the world, and allow supporting globalization. On the other hand railways are also on a technological rise thanks to high speed trains. The development of rails created different conditions for logistics since the steam revolution. The requirements of markets which demands fast and flexible deliveries shape the conditions for modern logistics. These factors plus constant urge to decrease cost of transportation determine international logistics activities.

Among all of these variables one thing remains unchanged. It is a geographical location. Turkey's location is since centruies complimented by business travelers, formerly by the caravan merchants, today by logistic operators. Observing the geographical location of Turkey it should be emphasized that it's strategically located on the cross roads between many regions of the world. Istanbul city formed between north and south over the Straits of Bosporus owes its historical role to exercised control over this geographically unique region. The route of the Silk Road was led by Turkey which has also become a cause of increasing power and wealth of the region in the period from $\mathrm{II}^{\text {rd }}$ to $\mathrm{XVII}^{\text {th }}$ century (Wood, 2002). The rise of global trade thanks to globalization processes opened also another area and directions for trade led from the Turkey.

Figure 1: Map of potential directions of transportation, using Turkish territory as a logistics hub (Isik, 2012)

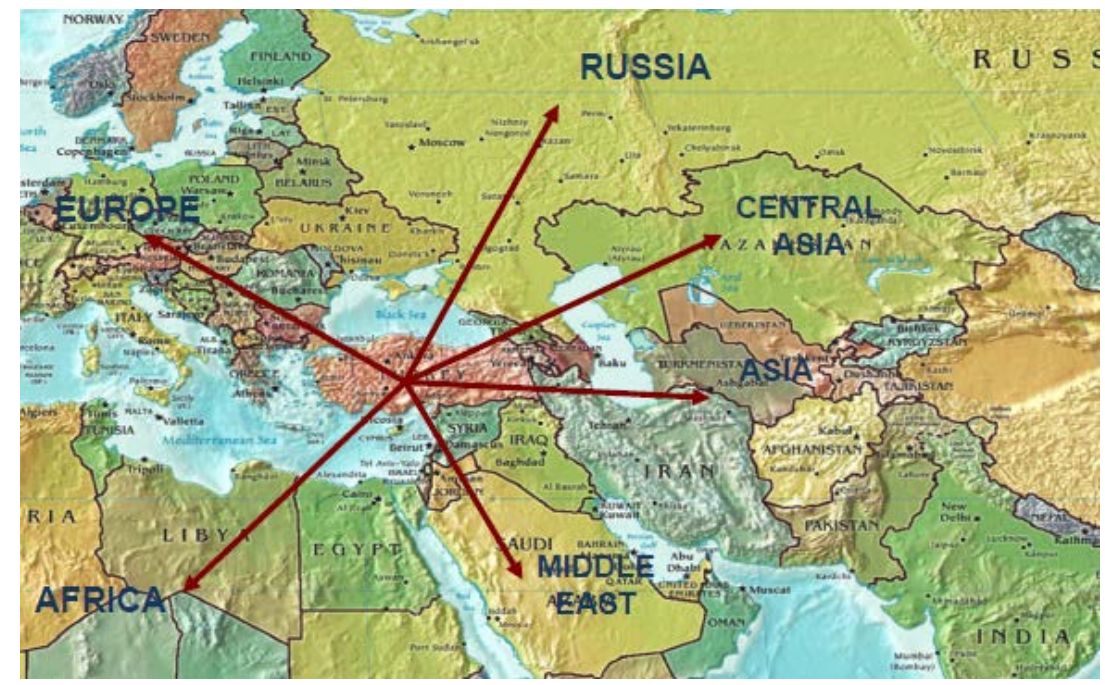


In Fig. 1 the main axis connects Europe and Asia. This connection is traditional land route for both directions and additionally connects two regions which need to cooperate close to fulfill its goals. Europe is an excellent distribution center and very profitable market. On the other side of this axis lies China - the biggest production center in the world. The fast growing economy needs an external market for the merchandise. The connection here could make cooperation between these both regions more fruitful and more adequate to modern market requirements in term of speed delivery. Another direction leads thru Caucasus to Central Asia. This direction allows unlocking resources of Central Asia countries and is supported by European at the beginning, TRACECA program. Similar direction leads to Russia. Thanks to the marine connections thru Bosporus Russia may be an excellent trade partner and distribution hub. Another direction heading Middle East and Africa are even easier to reach thanks to Mediterranean ports of Turkey like Izmir and Mersin. Trade exchange with Africa is arising opportunity in this region, growing thanks to foreign investments mostly from Asia. Additionally the Middle East connection is potentially profitable. Open Turkey for connectivity means allowing logistics operators to reach many densely populated areas and supplying them with products from European Asian axis. Gołembska and Szczyt stress the importance of the development of modern forms of transport and communications, and qualify them as one of the determinants of international trade development (Gołembska \& Szczyt, 2014). Recent studies indicate the anticipated growth of trade between EU countries and neighboring Turkey and Russia are expected to increase transport at the level of $100 \%$ between 2000 and 2020 (Stancu et al, 2014). That estimation was made before a political change in Ukraine. Since the climate of international relations recently worsteds the rotes which remains open and safe is Turkey. Thanks to both Asian and European effort to connect and increase trade this axis may become reality.

To conclude the superb geographical location it is worthy saying that Turkey lies on the Bosporus and Dardanelle Straits which connects Aegean (Mediterranean) and Marmara Seas. The control over an important merchandise marine route gives Turkey strategic advantage and allows developing a maritime infrastructure to use it as a source or logistical potential. The securing both sides of Bosporus gives Turkey ability to build and control land passages thru this strait. High speed railways and highway connections are critical to connect other logistical infrastructure on land deeper in the country territory.

Understanding of an attractive location is possible thanks to continuous effort in the field of logistical infrastructure development in Turkey. Thanks to the data from The Word Bank it is convenient to observe a multidirectional positive development of logistic performance for this region. By comparing the data from 2007 to 2014 and against the best performer in the word Germany it is clear how logistical performance in Turkey changes over this period and how far it must go to reach top performer. 
Table 1: Comparison of Turkey's 2007 - 2014 outputs in LPI with Germany (Ipi.worldbank.org, 2014)

\begin{tabular}{cccccccccc}
\hline Country & Year & $\begin{array}{l}\text { LPI } \\
\text { rank }\end{array}$ & $\begin{array}{l}\text { LPI } \\
\text { score }\end{array}$ & Customs & $\begin{array}{l}\text { Infra } \\
\text { structure }\end{array}$ & $\begin{array}{l}\text { Inter } \\
\text { national } \\
\text { shipments }\end{array}$ & $\begin{array}{l}\text { Logistics } \\
\text { competence }\end{array}$ & $\begin{array}{l}\text { Trancking } \\
\text { \& tracing }\end{array}$ & Timeliness \\
\hline Germany & 2014 & 1 & 4,12 & 4,10 & 4,32 & 3,74 & 4,12 & 4,17 & 4,36 \\
& 2014 & 30 & 3,5 & 3,23 & 3,53 & 3,18 & 3,64 & 3,77 & 3,68 \\
\multirow{2}{*}{ Turkey } & 2012 & 27 & 3,51 & 3,16 & 3,62 & 3,38 & 3,52 & 3,54 & 3,87 \\
& 2010 & 39 & 3,22 & 2,82 & 3,08 & 3,15 & 3,23 & 3,09 & 3,94 \\
& 2007 & 34 & 3,15 & 3,00 & 2,94 & 3,07 & 3,29 & 3,27 & 3,38 \\
\hline
\end{tabular}

For sure the Turkey's rank of LPI is impressive (2014 - 30). Especially form neighboring countries perspective (Bulgaria - 47, Greece - 44, Cyprus - 58, Syrian Arab Republic - 155, Iraq - 141, Armenia - 92, and Georgia - 116). This level of performance promote Turkey to standards popular among EU countries what is clearly visible in the LPI ranking where Turkey gets higher score than Poland, Czech Republic and Hungary. The three of moderately new EU members, with rather fast growing LPI score.

Figure 2: Comparison of Turkey's 2007 - 2014 outputs in LPI with Germany [lpi.worldbank.org, 2014]

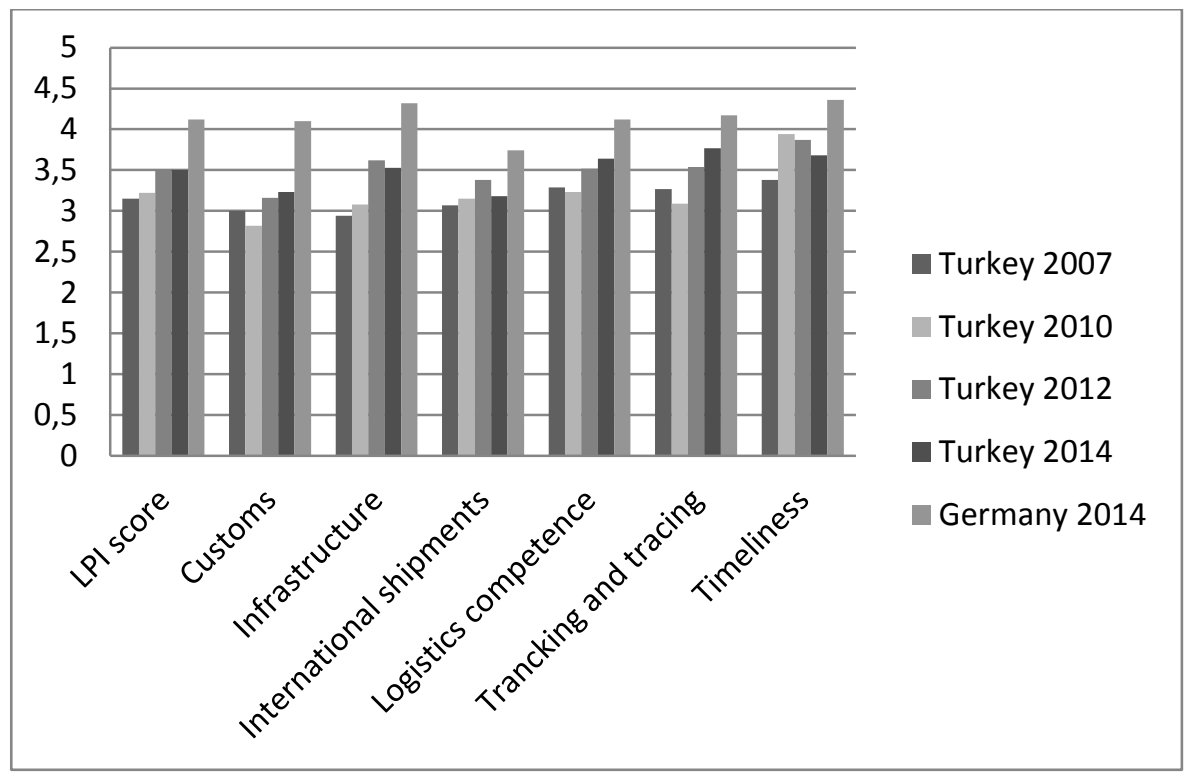

In all categories named by The World Bank Turkey is making progress. Meanwhile, the most observable is modernization of infrastructure. From 3,15 points in 2007 to 3,5 in 2014. This progress is an output of massive infrastructural projects in the field of transport constructions. Development of efficient passage crossing Bosporus and building high speed rail lines and highways triggering investment from private logistic sector. Izmir, Ankara and foremost Istanbul which holds $57 \%$ of the all projects in logistical sector, these are locations for warehousing infrastructure needed in densely populated areas. 
The global logistic operators appreciated Turkey as a potentially strong location. In the year 201323 European companies and nine US enterprises decided to construct an infrastructural logistics projects in Turkey (Camlica \& Nibbe, 2013).

The second fast growing area of logistical performance is logistical competence. Rise from 3,29 points in 2007 to present 3,64 shows that already build infrastructure have an skilled operators. I survey analyzing Foreign Direct Investment (FDI) the logistic industry in Turkey is growing fast. That is possible thanks to interest of international capital. Since 2007 to 2012 there has been noted 35 investments decisions in this field what gives $8,9 \%$ of all FDI project in Turkey during this time (Camlica \& Nibbe, 2013). This fact additionally underlines the potential of region and advantage of its localization. The rank of Turkey in LPI of the World Bank helps to realize its place among 160 countries. European Union countries are located in the top of it. Thanks to logistical cooperation in the European region these countries reduced the trade barriers mostly thanks to long-term investment in logistical infrastructure. That set a word example of cooperation in the region for increasing its performance. Eurologistics is a fine and special example of international logistics. As a country still in candidacy to EU its 30 place in this ranking shows that from perspective of logistic performance it is already there. The extensive plans in development or transportation project are also a good reason to improve warehousing facilities across Turkey. Since logistical cost of warehousing is in Turkey still an important factor the effort to decrease cost and increase efficiency of the process is worthwhile of additional attention. The optimal locations of the logistic centers are critical factor from the efficiency point of view.

Decreasing transportation cost, avoiding traffic in highly dense areas or having access to modern transportation infrastructure is at stake in planning locations of Logistic Centers. The plans announced by the government consist of building 19 new Logistic Centers by TCDD (Turkish State Railways) and a few by the private sector in a form of Public-Private Partnership such as Corlu and Manisa. Six of 19 state invested logistics centers are constructed and took into operations. According to TCDD's investment program, TCDD plans to spend TL 514.9 million on building logistics centers.

TL 111.4 million has already been spent on the project since 2006. The list of open projects in PPS consists of seven positions. These are operated by private consortia and will be handed over by Build-Operate-Transfer type (Deloitte Turkey, 2013). Although the time of constructing the net of logistic centers is still an undergoing project the result may be very profitable. Throughout simplifying the processes of transporting and warehousing products the operations will be quicker and less risky. The various demands will no longer be threatening especially to agricultural products. Gathering various activities under one roof is an ongoing trend in logistic industry. The role of logistic centers increases according to growing variability in demand. The quality of services available in such facilities decides if the product will be on time in the right place. Transferring functions to logistic centers may decrease delays and improve cost efficiency of operations. From storage, value adding activities to packaging and transport, the more integrated supply chain delivers better value faster than before. The access of producers to net of modern warehousing technologies may bring viable profits thanks to quickly developed track and trace technologies. Visibility and control of the cargo is a crucial part of modern logistics. 
The pace of the development in the area of tracking and tracing is in accordance with overall logistic performance in Turkey since 2007, as shown in Fig. 3. The plan of locating the net of Logistic Villages around the Trans-Asian Railway Network is based on possibility to connect the industry of Turkey with European and Asian regions. That can promote export in both directions and use its natural location superiority profitably for Turkish economy.

Figure 3: Development of Turkey's performance in LPI (2007 - 2014) (Ipi.worldbank.org, 2014)

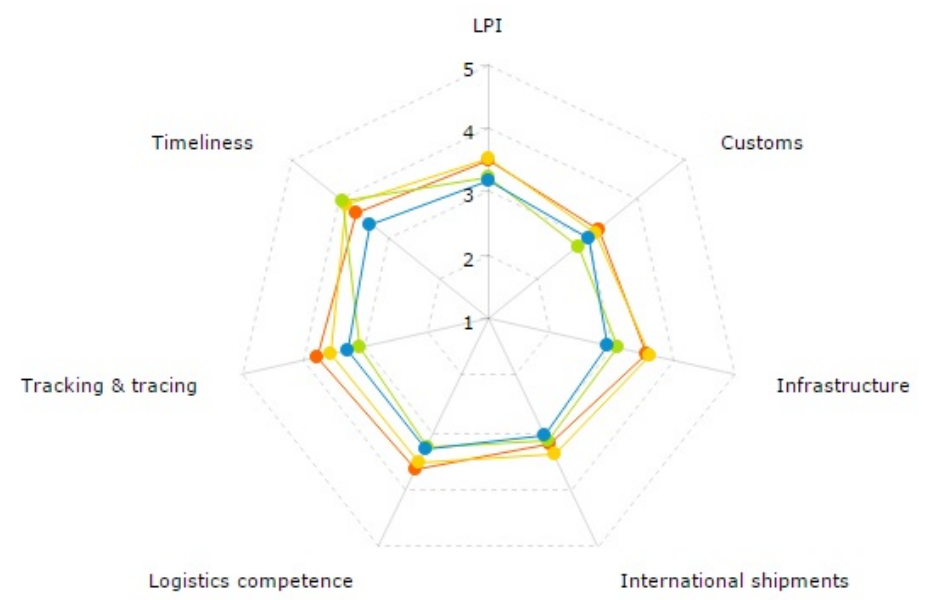

Turkey 2014

Turkey 2012

Turkey 2010

Turkey 2007

\section{EUROPEAN TRADE DEVELOPMENT AND TENDENCIES}

Trade is a source of development and prosperity. But to promote trade there must be certain conditions fulfilled. Logistic performance of the region determines the development of the trade. Employing of the innovative form of transportation helps to transport fast and efficiently. Ready and available logistic infrastructure like logistic centers ports, intermodal connections maintain the quality and secure the cargo. Simplification of the procedures in customs and reduction of tariff will speed up the logistics operations in the global scale (Gołembska, 2014).

As one of the leading trade partners in the world European region promotes logistics as a tool to unlock remote areas, speed the transportation and decrease the cost of trade. The constant effort in this matter dated at least since the beginning of UE project (1957) brings today a viable results. The leading top of the World Bank LPI ranking is full of UE countries (for 33 countries from the top of the ranking sorting 160 countries, 17 of them are UE countries). That fact promotes Europe as an world region to second place in the world with aggregated LPI score of 2,76. However the first place belongs to East Asia \& Pacific with LPI score of 2,85. This comparison is really important in the world of global supply chain. It explains the shift in production on the world scale. Europe once the biggest producer in the world now becomes the distribution hub for its partners. 
To maintain its position in the world trade and to be a valuable part of global supply chain Europe had to invest in the knowledge economy and fallow the specialization path. That allows it to cooperate with the biggest production hub lying in the South Asia. The European continent is a competitive area due to the economic advancement of the region and the financial strength capable of maintaining a high position in the forefront of countries making foreign direct investment (Bendini, 2014). Still there are other areas increasing its influence on the global economy. Update on top of the countries that are leaders of foreign trade orders to pay special attention to the United States, China, Russia, Japan, India and Brazil. According to forecasts, by 2015 90\% of world growth will be generated outside Europe. The third part of this increase would arise in China therefore the global supply chains of goods and services located all over the world must be prepared for increased transportation capacities (De Gucht, 2010). Thanks to the other sources the estimated growth of trade between EU and China is expected from $\$ 811$ billion to 1200 billion $\$$. In the tones of merchandise it is growth from 117 million (2014) to 170 million tons by the year 2020 (Almagambetov, 2015: 33). These can be considered as other reasons why China as a potential production hub in the world seeks efficient, fast and reliable connections with Europe. EU countries are important distributors for global supply chains. The involvement of China in revitalizing the New Silk Road serve for creating better conditions for trade than the arising TTIP agreement between the European Union and the United States.

International logistics chains serve such a configuration of manufacturing processes, which helps to achieve profits arising from the use of opportunities and potentials located anywhere in the world. These connections allow the achievements of modern logistics with a global reach. Countries with distinctive characteristics for creating qualitative or quantitative advantages in manufacturing processes create the potential available to logistic operators. This potential in Europe is highly developed technologies and logistics management systems as well. Developing countries like China, which in popular opinion gather most productive resources in the world, are forced to cooperate with manufacturers from Europe. Examples are high-tech products like smart phones produced officially in China, where more than half of the added value is created in Europe. An exemplary model of such a phone is marked as installed in China has added value in the range of $4 \%$ in China and $16 \%$ in Europe (De Gucht, 2014). As a result, EU countries are still at the forefront of world trade. The view on the trade as a source of influence must be supplemented by the statement that a partnership in trade allows to maintain a certain level or employment, and steady growth in the country economy. The global supply chains help to seek a potential and opportunity to deliver a value in more efficient way possible. In other words becoming an open economy helps to promote competitiveness by comparing the sources of value. It is worth to pay attention to what is the main product exported from Europe. The largest share in exports outside the EU is a group of products described as machinery and transport equipment. These products move mainly to the United States and China. This is an output of high specialization in the high-tech European industry. This is also associated with both: scientific and manufacturing potential of the Europe and as well economic growth in South Asia, mainly in China. 
The important trend is for global supply chains is the development of electronic commerce. The share of this sector of the economy grows as consumers' growing interest in the use of electronic applications in the process of meeting needs. The increase in purchases made through a network of Internet is increasing worldwide and at the especially high rate in China. By comparing growth in the years 2003-11, the total recorded in the US amounts for $17 \%$, Germany $22 \%$ and Japan $27 \%$. But in the same time to China it amounted to $120 \%$. That growth show how important it becomes for the economy of the country [Dobbs, Chen, 2013]. This proved an incentive to increase development of e-commerce and results in the development of logistics services. Courier services sector development necessary for the proper functioning of electronic distribution and is an area of potential growth for logistics activities. Native companies as SF Express, STO, as well as world leaders UPS, DHL invest in the area of China following the changing buying behavior of customers. Companies offering warehousing and logistics support contracts as SFC or USA Fulfillment expand storage infrastructure by creating a further basis for the development of e-economy. Singaporean firm Global Logistics Properties Ltd. intends to create a network of logistics centers in 33 cities in China. Online distributors like Alibaba, Jindong and Tencent invest sourced capital on the stock markets (like Alibaba - New York Stock Exchange) in the development of their own distribution structures (Dobbs \& Chen, 2013). Naturally, this is also a stimulus for the development of suitable logistics 3LP services in China giving a new dimension of speed and reliability of the tracking shipments and other services. The development of this form of distribution will connect the world in coming decades. Necessary increasing of logistics capacity seems only a matter of time. Expansion of the capacity of airports and air connections is a further consequence of this development. As a result, logistics services for the e-economy results in the creation of e-logistics. This is the current direction of development in modern supply chains, appreciate the flexibility provided by the rapid transmission and processing of information. Preparing the existing net of transportation between Europe and Asia for the challenges of the future development in worldwide distribution is thus a necessity.

\section{ASIAN DEVELOPMENT AS PRODUCTION CENTER OF THE WORLD}

East Asia \& Pacific as a region achieved first position in a global ranking of logistic performance in the year 2014. This is an excellent achievement mostly correlated to constant grow of Asian economies and increase in production sector. From the global supply chain perspective the Asian countries attract with its potential and efficiency many investors and thus become an important part of the value creating process for them. The changing climate in economy shows during the financial crisis in Europe that this dependability may be also a source of problems for the biggest countries especially China. To avoid risk the government of China tries to create an internal market helping to balance the disruption present on international market. That may also open new opportunities for other areas of the world for example Europe. Already strong bilateral trade exchange requires an efficient logistical support. Both regions as a world's leaders in logistic performance may use its logistical competence to connect and deliver value for their markets. China will rather continue to be a major production hub for many years because of the manufacturing and supply chain infrastructure it already has in place. 
However an increasing portion of that infrastructure may soon be devoted to meeting local needs, serving as well Western suppliers (Stuart, 2012). In order to maintain the attractiveness of regions benefiting so far from the trend to offshoring, China provides for a series of investments to improve logistics infrastructure. They are in the premise neutralize the negative characteristics of spatially distributed supply chains and deter investors before considering other alternatives to the shape of the supply chain. Far East Countries recognizing the problems of global supply chains and through a series of investments, both at the state level and private capital are trying to increase the attractiveness of their regions, also due to improving the logistic performance. The country representing the region is China. State with considerable economic potential has a vital importance for global supply chains. This is where the anticipated realization of many projects that may affect the efficiency of the logistics business partners of the Middle Kingdom.

Improving logistics infrastructure means investing in certain nodes of transport network as seaports, airports and linear infrastructure: road and rail links. While important for the economy of the country is increasing the efficiency of logistics in the area of China through connecting further areas of this gigantic country, it is crucial to minimizing the logistical problems of global supply chains to improve connections running outside of the area of China. In order to facilitate transport operations it is prepared a recovery plan of the known, historical Silk Road.

Figure 4: Map of the course of land and maritime The New Silk Road (Page, 2014)

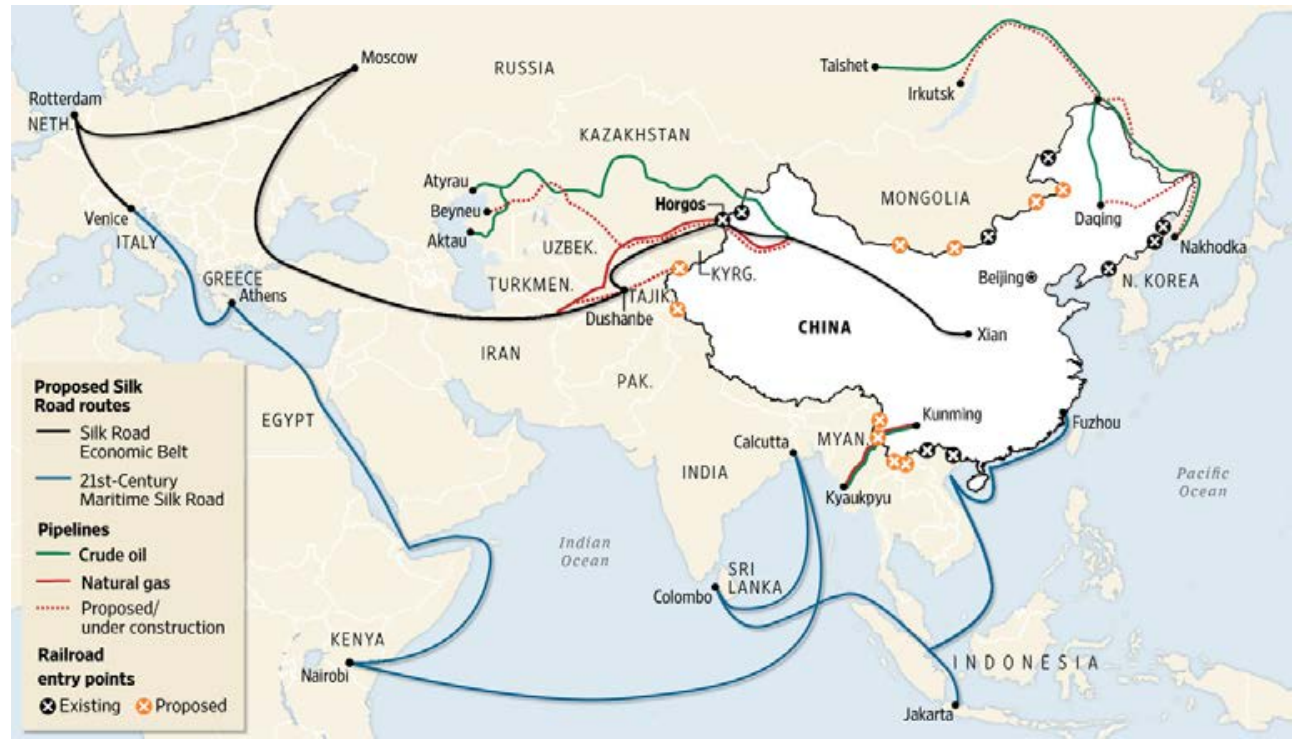

Thanks to external infrastructure investments implemented with multiple partners participating in the costs and benefits of the creation of the trail, China wants to create quick and reliable channels of transport linking South and East Asia with Europe. President Xi Jinping's plan has been based on solid foundations. First of all, the basic element is the agreement on free trade in Asia-Pacific. 
Another two pillars are: creating Asian Infrastructure investment bank with a capital of \$ 40 billion and fund the construction of the Silk Road with a capital of $\$ 40$ billion. However, this is only the beginning of the construction of the capital needed to implement the plans. Another, money will be available through investment of Chinese state-owned firms and private equity. With this project China aims to achieve the following objectives (Szczudlik-Tatar, 2013):

- Intensification of political cooperation between the connected regions to common economic development.

- Development of road connections, with the idea of establishing a transport corridor leading from the Pacific Ocean to the Baltic Sea and Central Asia to the Indian Ocean. Further expansion of the communication network between Asia, and eastern, western and southern regions.

- Facilitate the exchange of goods, with particular emphasis on the elimination of trade barriers and take steps to reduce logistics costs and investment;

- $\quad$ Strengthening monetary cooperation, with particular emphasis on currency settlement that could reduce transaction costs and minimize financial risk, while increasing economic competitiveness;

- Intensification of the tourist trade and an invitation to direct contacts.

In the interest of countries in Asia and the Pacific is improving transport networks, creating special corridors, securing logistical supply routes of raw materials and enabling the efficient transmission of information in flexible supply chains. The rapid increase in the share of e-economy in the development of logistics services provides tools to partners in the supply chain for performing the tasks of logistics services on a global level. Obtained thanks to modern infrastructure compression of time in carrying out transport operations, encourages global partners to benefit from the potential economies of the Far East. China is an example of an active investment policy for the region of South and East Asia. The impressive verve of the project to build the New Silk Road opens new possibilities for the future of China as a close partner of many of the logistics chain in Europe. The link Between Both regions must be logistically efficient and strategically placed. Thanks to the maps revealed by China it is obvious that such conjunction point will be located in Turkey.

\section{TRADE ROUTES BETWEEN ASIA AND EUROPE THROUGHOUT TURKEY}

Observing the geographical location of Turkey, should be emphasized its strategic location on the road between Europe and Asia. Istanbul city formed over the Straits of Bosporus owes its historical role to exercised control over this geographically unique region. The route of the Silk Road was led by Turkey which has also become a cause of increasing power and wealth of the region in the period from the third to the seventeenth century (Wood, 2002). Today such a location can be speciied as a potential logistics hub between Asia and Europe regions. The New Silk Road in fact consist of two separate projects Silk Road Economic Belt and Maritime Silk Road. The land route includes an Iron Silk Road. Employing rail transportation in the land part of The New Silk Road will increase speed or the transport. Modernize tracks can improve speed and safety of rail transportation. 
By building the tracks in the standard which allows using a high speed trains will make this mode of transportation three times faster than maritime. Additionally increase in speed is much less costly in comparison to airway transportation. The speed or deliveries is a critical factor in today's e-economy. Earlier mentioned development in e-logistics is an outcome of changing patterns in buying behavior of e-customers in Asia but also in Europe. This trend builds an interesting perspective in which logistics of deliveries is an important part of customization and may by perceived as a strategic advantage. Thanks to the Middle Corridor product can reach European destination within 8-9 days. In comparison to the maritime transportation which today takes $30-40$ days it is a significant difference (Acar, 2015a: 43). Planned route of the southern corridor of this trail leads from Singapore and the southern parts of China through India, Pakistan, and the territory of Iran to Turkey. Planned alternative branches of the New Silk Road are corridor and north central. Both routes run through the territory of Russia, which complicates the investment process. The current military conflict between Ukraine and Russia is an unfavorable factor impeding the implementation of construction transportation projects on this scale.

With the existing road and rail crossing through the Bosporus, the corridor through Turkey becomes feasible without waiting for the construction of new crossings. Across the trail route there are places to change the width of the tracks. The combination of European railway systems or standard $(1435 \mathrm{~mm})$, the South-East Asian $(1000 \mathrm{~mm})$, the former Soviet Union (1520) and the Indo-Pakistani $(1676 \mathrm{~mm})$ is necessary for the proper functioning of the route. A significant change was made concerning the route through Azerbaijan, Georgia to Turkey. The plans were simplified through bypassing Armenia (Sabah Daily Business, 2015). The omission of this country is due to the unfavorable outcome of the feasibility study of the project (Dabek, 2014). Despite this, it will be necessary to connect the European standard and the former Soviet Union tracks in the region Akhalkalaki station. Railway line linking the cities Kars-Tbilisi-Baku will be completed by the end of 2015 and it will be supplemented by the gas pipeline which will lead along, supplying the raw materials to Europe (Sabah Daily Business, 2015). It is also important to realize that thanks to robust economic and infrastructural links between Turkey, Georgia and Azerbaijan consist of three important projects. Baku-Tbilisi-Kars railway, Baku-TbilisiErzurum gas pipeline and Baku-Tbilisi-Ceyhan oil pipeline. The strong partnership is a matter off diplomatic effort and shows a positive effect thanks to trilateral contacts (Yukleyen \& Walsh, 2014: 16). By this way, a significant part of the infrastructure of the New Silk Road at the east of Turkey will become a reality. But, if it is delayed there might be other alternative routes to compete with it (Acar, 2015b)

Considering the investments already made in Turkey in the transportation construction it should be noted that projects in East-West direction support transportation of the New Silk Route. These investments will directly embody implementation of a recovery plan for the ancient Silk Road. Projects covering linear infrastructure upgrades along the course route consist of:

- High-speed railway line between Ankara and Istanbul.

- $\quad$ Route Marmaray part of the modernization of the railway infrastructure CR1 from Haydarpaşa to Gebze and from Halkali to Sirkeci. 
- $\quad$ Line of the Northern Marmara Motorway Motorway $260 \mathrm{~km}$ long.

- $\quad$ The Baku-Tbilisi-Kars Railway

- Pakistan-Iran-Turkey Railway

- Highway Istanbuł-Izmir

From a performance perspective, the expansion of inland transport rail line connections seems to be a priority for international communication in Turkey. The existing infrastructure is outdated and inadequate. According to plans of the Turkish Ministry of Transportation, Maritime Affairs and Communications for 2023 is designated to spend on the development of high-speed railways 45 billion \$. As a result of these expenditures it should appear railway infrastructure network, allowing driving speed of up to $250 \mathrm{~km} / \mathrm{h}$. Today the existing connection between Ankara and the city of Istanbul (Pendik station on the Asian side) proves the possibility of savings in transport time by using this technology. Duration of trip on this stretch is reduced from 6 hours $30 \mathrm{~m}$ to 3 hours (railwaytechnology.com, 2015). The existing connection Istanbul to Ankara is a section of the 533 $\mathrm{km}$ distance. It lies along the planned route of the New Silk Road. In 2012, Turkey signed an agreement with China to build high-speed lines connecting Edirne and Kars. This line runs across the whole territory of Turkey connecting an important railway junction Edirne with one of the transport corridor Orient - East Med, belonging to core network corridors of TEN-T funded by the EU. This combination of railway infrastructure enables efficient transit transport leading from the European Union by the Bosporus Strait, Turkey's territory up to the border town of Kars. This town becomes equally important hub for connecting to Turkey from the planned route of the Baku-Tbilisi-Kars. It is a project to build a rail link between Turkey, Georgia and Azerbaijan. The realization of the project would connect Edirne and Kars throughout 29 provinces within Turkey and shortened the time of travel from 36 to 12 hours. The whole investment is calculated at 35 billion \$. An important part of it - 30billion $\$$ will be incurred by The China Civil Engineering Construction Cooperation on the basis of separate agreements. The idea of this investment is closely associated with the project Baku-Tbilisi-Kars and therefore also financed from the funds of Chinese origin. This proves a great attention an interest of Chinese partners in realizing The New Silk Route. The other mentioned projects are also under various form of realization. This proves of serious development supporting the main route between Europe and Asia.

\section{CONCLUSIONS}

The perspective for future development in trade exchange between Asia and Europe leads to modernization of transport connections. The group of countries as Kazakhstan, Azerbaijan, Georgia, and Turkey are on the critical path connecting mentioned regions. Moreover the expected growth in trade and specialization in production and distribution for Eurasian supply chains increase the need for an efficient land and marine connection. The future capacity of the potential cargo explains undertaken investment and may allow many countries to play a vital role as a connecting hub for planned revitalization of The New Silk Route. Turkey observed by The World Bank shows some improvement in the score of logistical performance index. 
That is caused by an ambitious infrastructural plans both located by the Bosporus strait and along the East-west corridor. Additionally to that an important role for the development of the domestic logistic of the country plays development of the container ports and creation of logistic centers - logistic villages. These provide an efficient infrastructure, helping to maintain and operate expected increase in cargo transportation and making the whole path along The New Silk Road more flexible and competent.

The noted changes in behavior of the customers increase a pressure on fast delivery. The e-economy must be supported by e-logistics. That could provide the industry with the tools to control and manage the long and geographically stretched supply chain. Bearing in mind that the agility is a desired value in the modern supply chain, the feedback on every stage of the chain may play a crucial role in future adaptation to market fluctuations. To deliver that, the modern infrastructure is needed. The revival of Silk Route gives a chance to improve and modernize existing infrastructure to the level assuring the real competitiveness in term of speed and control of the resources during logistic operations.

The possibility for positive outcome of this multi-regional connection is high thanks to favorable approach of many nations involved in the process. China financial impute in the form of Asian Infrastructure investment bank provide the power to the national projects along the route. The European TRACECA project awakes the desire in Caucasus for a vital transport infrastructure and provides a platform for know-how exchange in the region. Additional to that, EU countries prepare from years a strong backbone for the industry and global supply chains in form of TEN-T corridors. That prepares an efficient infrastructure to the whole European continent and is an output of a Eurologistics perspective of policy in the region. The Turkey as a potentially critical logistical hub for Eurasia will indicate the development of the New Silk Route project. Observing changes in the logistic performance index may bring a useful conclusion along the realization of the route. The interest among many countries helps to draw attention of many investors and state capital for the modernization of the infrastructure and providing more transport capacities. This impressive plan could lead to beneficial decrease in cost of transportation and better control in the process. Moreover it may actually serve to strengthen the bonds in trade exchange among Eurasia

\section{REFERENCES}

Acar, A.Z. (2015a), The shortest route from Asia to Europe: Middle Corridor, Hazar World, Caspian Strategy Institute (HASEN), iss. 30 (May), p.43.

Acar, A.Z. (2015b), It's the right time: Competition on transportation corridor, Hazar World, Caspian Strategy Institute (HASEN), iss. 31 (June), pp.26-33.

Almagambetov, K.Y. (2015), Transport industry's competitive ability in the context of the New Silk Road Revival, Kazakhstan Logistics, No.8, p.33.

Ankara-Istanbul High-Speed Train Project Turkey, (01.05.2015), www.railway-technology.com.

Arvis, J.F. \& Shepherd, B. (2011), The Air Connectivity Index: Measuring Integration in the Global Air Transport Network, Policy Research Working Paper 5722, World Bank, Washington, DC. 
Arvis, J.R., Saslavsky, D., Ojala, L., Shepherd, B., Busch, Ch. \& Raj, A. (2014), Connecting to compete, Trade logistics in global economy, The International Bank for Reconstruction and Development, The World Bank, Washington, p.7.

Behar, A., Manners, P. \& Nelson, D.N. (2013), Exports and International Logistics, Oxford Bulletin of Economics and Statistics, University of Oxford and JohnWiley \& Sons Ltd., 75(June), p.880.

Bendini, R. (04.2014), The European Union and its trading partners, European Commission, DG TRADE.

Camlica, M. \& Nibbe, J. (2013), Ernst \& Young Attractiveness Survey, EYGM. p.23.

Dabek, M. (16.01.2014), Railway Destinies, The New Eastern Europe.

De Gucht, K. (11.2010), Trade, Growth and World Affairs, European Commission Trade, too: the WTO, Eurostat (Comext), p.4.

Dobbs, N. \& Chen, Y. (2013), China e-tail revolution; Online shopping as catalyst for growth, McKinsey Global Institute, March, p.1.

Global Rankings 2014, (2014), http://lpi.worldbank.org/.

Gołembska, E. (2014), Logistyka międzynarodowa, PWN, Warszawa, p.73.

Gołembska, E. \& Szczyt, M. (2014), Czynniki stymulujące rozwój logistyki międzynarodowej w warunkach zmienności gospodarki światowej, in: Gołembska E., Bentyn Z., Logistyka międzynarodowa w zmiennych warunkach gospodarki światowej, Wydawnictwo Uniwersytetu Ekonomicznego w Poznaniu, Poznan, p.9.

Isik, I. (29.03.2012), Intermodal Transport in Turkey, Ministry of transport and maritime affairs and communications, Ankara.

Sabah Daily Business, (5.02.2015), Kars-Tbilisi-Baku railway line to open in 2015.

Sabah Daily Business, (07.03.2015), Turkey, Georgia, Azerbaijan mull building new Silk Road.

Page, J. (09.01.2014), China Sees Itself at Center of New Asian Order, The Wall Street Journal.

Shepherd, B. (2013), Aid for trade and value chains in transport and logistics, OECD WTO Report, p.27

Stancu, I., Vărzaru, M. \& Lăzărescu, A., (2014), Helsinki Corridors: Ways of European Expansion and Development, European Research Studies, V. XVII, I.(2).

Stuart, S. (03.2012), Supply Chain Matters: The Asian Battleground, A World of Insight, spencerstuart.com.

Szczudlik-Tatar, J. (12.2013), China's New Silk Road Diplomacy, Policy Paper, Polski Instytut Spraw Międzynarodowych, N.34(82).

The Logistic Industry in Turkey, (11.2013), Ministry of Transport Maritime Affairs and Communications, Deloitte Turkey, p.97.

Wood, F. (2002) The Silk Road: two thousand years in the heart of Asia. Berkeley: University of California Press.

Yukleyen, A. \& Walsh, J. (2014), Georgia Crossroads of the Caucasus, Caspian Strategy Institute (HASEN). 